\title{
NIETZSCHE: NIILISMO E GENEALOGIA MORAL
}

\author{
Eduardo Carlos Bianca Bittar \\ Professor Doutor do Departamento de Filosofia \\ e Teoria Geral do Direito da Faculdade de \\ Direito da Universidade de São Paulo
}

\begin{abstract}
Resumo:
O pensamento de Nietzsche e sua filosofia traduzida pelo niilismo e o voluntarismo, A filosofia moral de Nietzsche: a moral dos senhores e a moral dos escravos é um dos tópicos importantes abordados pelo autor, que apresenta as conclusōes da obra do filósofo no término deste artigo.
\end{abstract}

\begin{abstract}
:
The Nietzsche's thought and its Philosophy translated by nihilismus and voluntarism. Its moral Philosophy: the owner's and slaver's moral is one of the most importants topycs boarded by the author, that presents conclusions along the Philosopher work in the end of this article.
\end{abstract}

Unitermos: Nietzsche; niilismo; voluntarismo; Justiça; sociedade; Direito.

1. Traços e linhas nietzschianos.

Friedrich Wilhelm Nietzsche (1844-1900), filósofo de origem alemã, é identificado como teórico do voluntarismo e do niilismo filosóficos. Seu pensamento se debruça sobre temas das mais diversas latitudes, mas se destacam suas preocupações sobre areligião e a moral como pontos-chave de seus textos. De fato, suas elocubrações possuem incursões sobre muitas temáticas (história, música, filologia, religião...) e, inclusive, sobre a temática moral. Ao deitar-se sobre os valores e ao discutir sobre crenças é que causa profundos abalos na consciência coletiva ocidental, com as propostas que caracterizam sua filosofia niilista. Antes de se tornar autor de reconhecida nomeada em sua época, chegou a se destacar em filologia, tornando-se professor desta ciência na Universidade de Basiléia.

Marcos fortes de sua personalidade e de sua biografia são suas influências trazidas do ceticismo de Schopenhauer' e da musicalidade de Richard Wagner. A abrupta ruptura de relações com este último foi de capital importância para sua vida e para sua filosofia, algo que só ocorreu quando da publicação de Humano, demasiadamente 
humano (1878), quando Nietzsche fere os principais valores tradicionais e religiosos de Wagner com seus pensamentos. A partir de então, não-somente sua filosofia passa a ganhar maior alento, inclusive em número de obras, como seu degringolar vai paulatinamente se desencadeando, até a veemente loucura, sob a vigília da irmã, e morte, em 1900.

Destacam-se, do amplo rol de textos de sua autoria, as principais obras de Nietzsche, aí compreendidas aquelas da fase de sua amizade com Wagner (até 1878), e também as da fase de quebra da amizade com Wagner (após 1878): 1872 - $O$ nascimento da tragédia; 1873 A filosofia na idade clássica dos gregos (publicado postumamente: Verdade e mentira no sentido extramoral); 1878 Humano, demasiadamente humano; 1882 - A gaia ciência; 1883-1885 - Assim falou Zaratrusta; 1886 - Para além do bem e do mal; 1887 A genealogia da moral; 1888 - Ecce homo: como me tornei eu mesmo.

Mas, o que faz com que se busque em sua obra os traços de suas idéias morais, e de sua influência sobre a ética contemporânea, é a frase enigmática por ele lançada em sua autobiografia, que aqui se reproduz:

"A questão da origem dos valores morais é, portanto, para mim de primeira ordem porque dela depende o futuro da humanidade" (Nietzsche, Ecce homo: como cheguei a ser o que sou, p. 131).

2. Alguns postulados da filosofia nietzschiana: niilismo e voluntarismo.

Estes são os pontos de maior destaque da fillosofia de Nietzsche: o voluntarismo e o niilismo. Tendo em vista estes marcos, é de grande importância que sejam bem definidos nesta parte, antes que se inicie propriamente a reflexão sobre sua filosofia moral.

Quanto ao seu niilismo, há que se dizer que é ponto marcante e de distinção na obra de Nietzsche, sobretudo em sua obra tardia, a partir de $1881 .^{2} \mathrm{~A}$

1. Leia-se, em A genealogia da moral, esta declaração de Nietzsche sobre seu encantamento com as idéias de Schopenhauer: "Do que cu tratava era do valor da moral; acerca desse ponto eu não linha que explicar-ıne senão para o meu ilustre Schopenhauer, a quem se dirigia este livro com toda sua paixão e a sua secreta oposição (porque "Humano, demasiadamente humano", era, com esta, uma obra de polêmica)" (Nietzsche, A genealogia da moral, 1991, p. XIII).

2. Cf. Araldi, Para uma caracterizą̧āo do niilismo na obra furdia de Nietzsche. Cadernos Nietzsche, São Paulo, v. 5, 1998, p. 75. Destaca-se neste artigo que as obras Para a genealogia da moral, O creptisculo, dos ídolos e $O$ anticristo são as que mais caracteristicamente possuem traços niilistas. 
princípio, pode-se tratar de mera coincidência, mas há uma certa proximidade entre a palavra alemã para significar a idéia do 'nada' e o nome de nosso filósofo niilista (Nietzsche). Até nisto se identificam e se comunicam, nome do autor e obra. A própria idéia de moral será investigada dentro desta concepção do niilismo, e será metodologicamente devassada como fruto do niilismo ocidental. Ou ainda, a própria idéia de moral em Nietzsche é que funda o niilismo. ${ }^{3}$

Veja-se o sentido de niilismo na obra de Nietzsche:

"Niilismo. Nietzsche é o único a não-utilizar esse termo com intuitos polêmicos, empregando-o para qualificar sua oposição radical aos valores morais tradicionais e às tradicionais crenças metafísicas: 'O niilismo não é somente un conjunto de considerações sobre o tema Tudo é elm vão, não é somente a crença de que tudo merece morrer, mas consiste em colocar a mão na massa, em destruir; (...) É o estado dos espíritos fortes e das vontades fortes do qual não é possivel atribuir um juizo negativo: a negação ativa corresponde mais à sua natureza profunda (Willw zur Macht, ed. Kröner, XV, parágrafo 24)" (Abbagnano, Dicionário de filosofia, 2000, pp. 712/713, Termo: Niilismo).

Com outras palavras, se pode dizer que:

"Com o termo niilismo (der Niilismus), ele procurava abarcar as diversas manifestações da doença ou crise inscritas na história do homem ocidental, de modo a atingir a razão comum dessa doença, qual seja, a instauração da interpretação moral da existência dá origem ao niilismo ocidental" (Araldi, Para uma caracterização do niilismo na obra tardia de Nietzsche, Cadernos Nietzsche, São Paulo, v. 5, 1998, p. 76).

Então é que Nietzsche desenvolve sua filosofia como um profundo trabalho de escavação dos valores, no sentido de superá-los como negação da vida. Ora, o niilismo é a raiz de toda a cultura ocidental, que desenvolveu uma forma de

3. "Desse modo, constata-se que o niilismo assume importância e significação na obra tardia de Nietzsche a partir da investigação da história da moral" (Araldi, Para uma caracterização do niilismo na obra turdia de Nietzsche, Cadernos Nietzsche, São Paulo, v. 5, 1998, p. 76). 
pensar em que o auto-aniquilamento é visto como virtude, em que a dor é exaltada como um bem, em que o tédio da vida é parte do viver mundano. A história do Ocidente está recheada de exemplos disto, como demonstra Nietzsche. ${ }^{4}$ A origem de tudo isto seria a própria religião, que exalta o transcendente em detrimento do presente, a espiritualidade, em detrimento da materialidade, menosprezando os valores humanos, bem como a rica e extensa condição humana.

Ora, o empenho de Nietzsche seria o de superar este modus com o qual se constituíram os valores no Ocidente, bem como o de embrenhar-se na tarefa de destruição dos arquétipos que a eles deram origem. A superação disto daria vazão à possibilidade de inserção de novos valores para os homens, valores humanos, voltados para a satisfação humana, sem a altivez e a uniformidade da 'ciência da moral' tal como altiva e tradicionalmente concebida: ${ }^{5}$

\section{"Até o próprio título "ciência da moral" é relativamente àquilo que quer significar muito pretensioso e contrário ao bom gosto, que prefere expressões mais modestas" (Nietzsche, Além do bem e do mal, 2001, p. 119).}

É assim que se inscrevem, finalmente, as tendências niilistas no pensamento de Nietzsche, em graus e diferenças de sentido:

1. Niilismo incompleto (unvollständig Nihilismus) e niilismo completo (vollkommener Nihilismus): a morte do deus cristão, no niilismo incompleto, é decorrência do espírito da modernidade, vazio que é preenchido por outras idéias (progresso, ciência...); a morte do deus cristão, no niilismo completo, é sabida, sentida

4. "Através de considerações históricas, o filósofo mostra a ação das epidemias da saciedade de viver, dentre as quais ele cita a dança macabra de 1348, o pessimisıno parisiense de 1850, o alcoolismo na Idade Média, a depressão na Alemanha depois da guerra dos Trinta anos (GM/GM III, 13). Ocorrendo em vários momentos da história, essa vontade que se volta contra a vida mostra sua origem a partir do instinto de espiritualidade que quer negar a natureza e tem como conseqüencia o toedium vitae, a saciedade de viver, o niilisıno" (Araldi, Para uma caracterização do niilismo na obra tardia de Nietzsche, Cadernos Nietzsche, São Paulo, v. 5, 1998, p. 83).

5. "Através da investigação da História nutural da moral, o niilisıno é compreendido como doença, como transcurso doentio típico, adquirindo desse modo estatuto de questão fundamental, a partir da qual seria possível criticar-destruir a moral existente e possibilitar a criação de novos valores" (Araldi, Para uma caracterização do niilismo na obra tardia de Nietzsche, Cadernos Nietzsche, São Paulo, v. 5, 1998, p. 84).

6. "É nesse sentido que Nietzsche distingue entre niilisıno incompleto e niilisıno completo. No niilismo incompleto (unvollständig Nihilismus) há a tentativa de preencher o vazio decorrente da morte do deus cristão, tido como a fonte da verdade (XII, 10,42). Através de ideais laicizados (o progresso na história, a razão moral, a ciência, a democracia), os homens ainda mantên o lugar outrora ocupado por Deus, o supra-sensível, pois buscam algo que ordene categoricamente, a qual possam se entregar absolutamente. 
e refletida, sendo que em sua substituição nada se tenta trazer. ${ }^{\circ}$ A Europa vive um Niilismo incompleto, na busca de substituição da ausência do Deus cristão por outras ideologias, algo que deve ser superado pelo Niilismo completo, na proposta de Nietzsche;

2. Niilismo completo, ativo e do êxtase (ekstatischer Nihilismus): na proposta de Nietzsche, não basta contemplar a morte do Deus cristão, muito menos a ausência do que lazer para substituí-lo na luga do medo do vazio. O Niilismo completo assume a ausência do Deus cristão, e funda uma cultura de superação desta ausência pela vivência de novos valores laicizados e independentes da opressão deste jugo. Enfïm, proceder desta forma é transvalorar os valores, alcançando um êxtase humano, profundamente humano.?

Assim se confirma em sua postura teórica uma profunda pregação contra a religião e a moral tradicionais, bem como contra toda e qualquer filosofia metafísica, ${ }^{8}$ pois identifica nestes filósofos verdadeiros sacerdotes disfarçados e nos moralistas verdadeiros raquíticos da investigação moral. Em suas concepções, devem ser desfeitas todas as amarras possíveis à vontade de potência. E é isto que abre campo para que se explique melhor as idéias de voluntarismo e vontade de poder em seu pensamento.

Assim, quanto ao seu voluntarismo, é de se dizer: o motor da ação não

Em suma, no niilismo incompleto há a tentativa de superar o niilisıno seın transvalorar os valores (XII, 10, 42). No niilisıno completo (vollkommener Nihilismus) há uma auto-consciência do hoıneın sobre si próprio e sobre a sua nova situação após a morte de Deus (XII, 10,42). Esta forma de niilisino é uma consequiência necessária dos vảlores estimados até então como superiores. Nesse momento, contudo, não ocorre aunda a criação de valores afirmativos: o niilista completo não consegue mais mascarar, através de ideais e ficções, a vontade de nada. Não é apenas o supra-sensível que é abolido, mas taınbém a oposição entre ambos (GD/CI. Como o mundo verdadeiro tornou-se fábula). Com um olhar pálido, desfigurado, o niilista completo contempla e idealiza a partir da fraqueza. A completude do niilisıno não ocorre somente nessa dissolução passiva, no tipo do decadente que frui passivamente de seu esgotamento. É nesse sentido que o filósofo distingue entre niilisıno ativo c niilismo passivo" (Araldi, Para uma caracterizacião) do) niilismo na obra tardia de Nietzsche, Cadernos Nietzsche, São Paulo, v. 5, 1998, p.86).

7. "Nietzsche pretende passar do niilisıno incompleto, que é ainda a condição da modernidade, para o niilismo completo e, posteriormente, pra o momento derradeiro: o niilismo do êxtase (ekstutischer Nihilismuıs). O tipo de homem afirmativo não se detém na negação (tudo é em vão) e suas consequiências: a derrocada de todo sentido e a decadência fisiológica. Desse modo, no niilismo do êxtase há a necessidade de destruir ativamente, visto que a destruição é uma condição para a criação de novos valores. Enquanto "a mais divina de todas as formas de pensar", o niilismo funciona como um martelo na mão do criador. Com isto chega-se ao niilișmo do êxtase, que é condição para se chegar à suprema afirmação da existência" (Araldi, Para uma caracterizaçāo do niilismo na obra tardia de Nietzsche, Cadernos Nietzsche, São Paulo, v. 5, 1998, p. 88).

8. "O compromisso de Nietzsche não é com a defesa do universal ou da racionalidade, ınas com a efetividade. Por isso, denuncia todas as formas que viabilizam a sua depreciação. A sua crítica à moral, à religiāo, à filosofia e à ciência tem por base o resgate da supremacia da imanência e, nesse sentido, visa a excluir a transposição do valor ao plano transcendente" (Azeredo, Nietzsche e a dissolução da moral, 2000, p. 177). 
está no fim (finalismo), no teleologismo, (télos: fim, greg.), mas na vontade de poder que move todo ser existente, desde o vegetal até o ser humano. Ora, voluntarismo é, nesse sentido, a submissão de tudo à idéia de vontade, à noção de que o apetite é que movimenta as mudanças e as operações na condição mundana. Em poucas palavras:

"O mundo visto por dentro, definido e determinado por seu "caráter inteligivel" seria-precisamente - "vontade de potência" e nada mais" (Nietzsche, Além do bem e do mal, 2001, p. 61)..

A vontade é a flecha chamejante que propulsiona todo existente para adiante, nas palavras de Zaratrusta:"

"Entretanto, Zaratrusta olhava a multidão com assombro. Efalou assim:

Amo o que ama a sua virtude; porque a virtude é desejo de perecer e flecha do infinito desejo" (Nietzsche, F. W., Assim falava Zaratrusta, 1973, p. 15).

Nisto não existe nem transcendência metafísica e nem inércia cética, mas sim uma postura profundamente visceral a tudo o que é mundano: a vontade, o princípio de tudo. ${ }^{10}$

As coisas não possuem sentido por si mesmas, pois é a vontade que lhes determina o sentido." É esta vontade o governo de tudo, pois se trata de algo profundamente próprio ao ser humano, que deve ter vontade de superação, de se tornar mais do que tradicionalmente é, mais do que efetivamente se permite ser. Isto tudo porque a vontade de potência tem sido reprimida, intensa e sucessivamente, pelos costumes e pela moral tradicionais. ${ }^{12}$ Camuflar esta vontade é a pior das estratégias possíveis, isto porque:

9. A posição de Nietzsche é muito bem definida nestas palavras, quando diz que toda energia poderia ser chamada vontade potência: "Suponho, finalmente, que se chegasse a explicar toda nossa vida instintiva como o desenvolvimento da vontade - da vontade de potência, é minha tese - teria adquirido o desejo de chamar a toda energia, seja qual for, vontade de potênciu" (Nielzsche, Além do Bem e do Mal, 200I, p.6I).

10. “A concepção de realidade como uma explosão exuberante de vida incontrolável induz Niezsche a interpretar a história segundo o princípio grego do eterno retorno: tudo nasce, morre e volta a nascer de novo, sem fim" (Masip, História da filosofia ocidental, 2001, p. 269). Nisto, a vontade é o motor de tudo, mas especificamente, a vontade de poder.

11. "O homem, eın Nietzsche, é delinido como aquele que avalia, que confere sentido às coisas. $O$ homem é vontade de potência" (Azeredo, Nietzsche e a dissoluçăo da moral, 2000, p. 73).

12. "Esse é o papel fundamental da moralidade do costume e da tradição: inscrever no homem o social, conter-lhe os instintos" (Azeredo, Nietzsche e a dissoluçäo da moral, 2000, p. 95). 
"O ser vivo necessita e quer, antes de mais nada e acima de todas as coisas, dar liberdade de ação à sua força, ao seu potencial. A própria vida é vontade de potência" (Nietzsche, Além do bem e do mal, 2001, p. 33).

Em Nietzsche, somente a vontade pode romper o ciclo de acalentamento do homem da noção de que sua condição é miserável, e de que deve aguardar outra condição transcendente que seja melhor que esta. Não, definitivamente, não! Para Nietzsche a vontade pode, na medida em que está visceralmente ligada a uma capacidade humana, a algo que é humano, demasiadamente humano. Cumpram-se assim as palavras de Zaratrusta:

"Restituí, como eu restitui à terra, a virtude extraviada, restituí-a ao corpo e à vida, para que dê à terra o seu verdadeiro sentido, um sentido humano" (Nietzsche, Assim falava Zaratrusta, 1973, p. 85).

3. A filosofia moral nietzschiana.

A moral não é nem rejeitada e nem recusada por Nietzsche, muito menos aceita do jeito que tradicionalmente é concebida. Mas, de qualquer forma, o que se pode, preliminarmente, dizer sobre o tema, é que a realidade moral em si mesma não existe, mas sim uma interpretação moral dos fenômenos:

"Não existem fenômenos morais, mas uma interpretação moral dos fenômenos" (Nietzsche, Além do bem e do mal, 2001, p. 102).

Ao afirmar isto, Nietzsche quer exatamente fundar um pensamento que traga o homem às origens de si, à investigação sincera e objetiva (entenda-se nãomascarada), arqueológica e fundamental, genealógica (génesis, greg., gênese, origem) dos valores e crenças humanos. Nietzsche quer destacar o quanto o homem é demasiadamente humano, e, neste sentido, não poderia negar a existência da moral, ou mesmo a sua importância. Mas, haverá de conferir a ela um outro sentido, bastante peculiar, através de suas pesquisas.

O que Nietzsche haverá de fazer será re-fundar a moral, a partir de uma certa metódica arqueológica que escava a história, valorando-a de outra forma, 
compreendendo-a de outra forma, a ponto de transformar o significado das ações, dos feitos, e o simbolismo de determinadas crenças. Para isto é necessário analisar a procedência dos valores, e verificar, historicamente e logicamente, como se formaram e se deformaram: ${ }^{13}$

"Necessitamos uma crítica dos valores morais, e antes de tudo deve discutir-se o "valor destes valores", e por isso é de toda a necessidade conhecer as condições e os meios ambientes em que nasceram, em que se desenvolveram e deformaram (a moral como conseqüência, máscara, hipocrisia, enfermidade ou equivoco, e também a moral causa, remédio, estimulante, freio ou veneno) conhecimento tal que nunca teve outro semelhante nem é possivel que tenha" (Nietzsche, A genealogia da moral, 1991, p. XIV).

Nietzsche tem uma recomendação neste sentido, qual seja, a de que seja superada definitivamente a moral tradicional, entendendo-se aí residir a moral cristã e a metafísica platônica. Eis o alerta: Alijai-vos da opressão do passado moral, pois a moral corresponde à cristalização dos valores do passado, e tornar-se um fiel guardião dos mesmos não é exercer a liberdade ética, mas submeter-se a padrões morais arraigados ao passado! Com esta preocupação é que Nietzsche se lança na empreitada de discutir a questão ética.

As descobertas de que o homem ocidental é niilista, e de que encontra-se à deriva da concepção de Deus, substituído por subterfúgios outros da razão, e, sobretudo, de que o homem ocidental despreza profundamente a si mesmo, são determinantes para a obra do filósofo alemão. É por isso que em sua autobiografia (Ecce homo) afirma que "Com Aurora comecei a luta contra a moral da renúncia a si mesmo" ${ }^{14}$ Com este desprezo, acaba por esquecer-se de valorar o que é humano, para valorar o que é transcendente. Tudo isto é detectado pelo procedimento teórico adotado por Nietzsche para investigar a moral: a genealogia. ${ }^{15}$ Percebam-se as palavras de Nietzsche:

13. "Analisar a procedência de um valor remete necessariamente às suas condiçōes de criação, por isso a pergunta 'quem?' fundamental em Nietzsche, por introduzir como procedimento norteador, que permite desvendar as perspectivas implicadas nas avaliações e, portanto, estabelecer o valor dos próprios valores" (Azeredo, Nietzsche e a dissolução da moral, 2000, p. 35).

14. Nietzsche, Ecce homo: como cheguei a ser o que sou, p. 133.

15. “É a partir da história da moral que o filósofo procurará caracterizar e validar metodologicamente as diversas formas de niilismo. Ou seja, o niilismo foi cunhado na obra de Nietzsche a partir da investigação da moral, da qual resul ta a elaboração de um novo inétodo de análise da moral: o procedimento genealógico" (Araldi, Para uma caracterizaşăa do niilismo na obra tardia de Nietzsche, Cadernos Nietzsche, São Paulo, v. 5, 1998, p. 78). 
"Se abstraímos do ideal ascético, vemos que o homem não teve até agora finalidade. A sua existência sobre a Terra carece de objetivo. "Por que o homem?" Eis uma pergunta sem resposta; o homem e a terra não tinham liberdade; em cada passo do destino humano ressonava este grito. "Em vão!" Eis a finalidade de todo o ideal ascético; queria dizer que em volta do homem havia uma imensa "lacuna"; não sabia justificar-se a si mesmo, interpreta-se, afirmar-se; sofria ante o problema da vida. E sofria de muitas maneiras; era antes de tudo um animal "doente" o seu problema, porém, não era a dor. "O homem, o animal mais valoroso e enfermiço, não repele dor, antes a procura, contando que lhe digam o porquê" (Nietzsche, A genealogia da moral, 1991, p. 113).

Assim, desloca-se o eixo de preocupações morais do valor para o valor do valor, na postura de transvaloração dos valores. " E, após a constatação dos erros da moral do passado, não basta simplesmente accitar ou conhecer este fato, pois torna-se imperativo desmistificar diversos dos ídolos construídos como norteadores da conduta moral, ou ainda, carece desconstruir o passado, para revesti-lo de novo simbolismo que propulsione os indivíduos para o futuro. Eis a necessidade do martelo ${ }^{17}$ nietzschiano para efetivar este projeto. ${ }^{1 \nless}$ Este martelo funciona, sobretudo, contra a inocência do

16. “É como herdeiro da mais longa e corajosa auto-superação que a Europa moralizada realizou sobre si mesma que Nietzsche compreende a si mesmo e a sua tarefa filosófica; é como imnoralista que se apropria da tradição milenar, para assim instaurar o projeto de transvaloração dos valores" (Araldi, Para uma caracterização do niilismo na obra tardia de Nietzsche, Cadernos Nietzsche, São Paulo, v. 5, 1998, p. 84).

17. O martelo de Nietzsche se dirige contra a filosofia antecedente, contra os costumes cristalizados, contra a religião judaico-cristã, contra os cânones metalísico-platônicos, e contra todo obstáculo que se anteponha à superação da moral tradicional. Eis um exemplo da ação de seu martelo: "A hipocrisia inflexível e virtuosa com que o velho Kant nos conduz por todas as veredas de sua dialética para nos induzir a aceitar o seu pensamento categórico é uın espetáculo que nos faz sentir o imenso prazer de descobrir as pequenas e maliciosas sutilezas dos velhos moralistas e dos pregadores. Somemos a tudo isso o malabarismo, pretensamente matemático, com que Spinoza termina por escudar e mascarar sua filosofia, tratando de intimidar assim, desde o princípio a audácia do assaltante que pousa os olhos numa virgem invencível: Palas Atenas. Como se pode entrever, por meio de tão qequeno broquel e inútil máscara, a timidez e a vulnerabilidade de um ser doente e solitário!" (Nietzsche, Além do bem e do mal, 2001, pp. 23-24).

18. "Daí a posição indiferente que se efetivaria na manutenção do dado ser objeto de crítica e, porque não dizer, ideal a ser destruído pelo 'inartelo', já que a crítica, enquanto referida ao valor dos valores, configura a "filosofia a marteladas', destruidora de idéias e ideais" (Azeredo, Nietzsche e a dissolu̧̧ão da moral, 2000, p. 26). 
moralista, quando se trata de inscrever o método genealógico como o único instrumento de re-avaliação da história da moral:

"O sentimento moral na Europa é atualmente tão fino, tardio, múltiplo, irritável, refinado, quanto a "ciência moral" é ainda jovem, principiante, entorpecida $e$ grosseira; um contraste atraente, que por vezes se manifesta na própria pessoa do moralista" (Nictzsche, Além do Bem e do Mal, 2001, p. 119).

É com o grande martelo que procura demolir a tradição judaico-cristã, e platônico-metafísica, bem como insculpir-se a filosofia nietzschiana da suspeita, da dúvida, da transvaloração, da re-construção do saber ético ocidental, o que se faz com conhecimento e a consciência de que as heranças do passado determinaram o presente, o que só se faz por meio da genealogia. ${ }^{19}$ Sem hipocrisias e falsos moralismos, a ética nietzschiana é fruto de uma ruptura com a tradição, algo condizente com o espírito livre de seu autor. ${ }^{20}$ Este legado de suspeita e esta tentativa de libertação do passado medieval é que haverão de movimentar boa parte das correntes de pensamento do século XX.

\subsection{A genealogia da moral: moral dos senhores e moral dos escravos.}

O passado subjuga o presente e determina o futuro. Empenhado em romper com este ciclo é que Nietzsche se lança na empreitada de investigar como se organizaram os valores no passado, para que se pudessem desvendar as tipologias da moral ocidental e o modus de entendimento da moral pelo homem ocidental. É assim que o filósofo alemão chega a identificar a moral dos senhores e a moral dos escravos. ${ }^{21}$

19. "É claro que o genealogista da moral há uma cor cem vezes preferível ao azul, a cor parda, isto é, tudo o que se funda em documentos, tudo o que consta que existiu, todo o longo tex to hieroglífico, laborioso, quase indecifrável do passado da moral humana" (Nietzsche, A Genealogia da Moral, 1991, p. XV).

20. "Somente uma inversão radical (Umkehrung) de todos os valores, que não pode ser obra da razão mas deve ser levada a cabo pelo instinto ou pela vida em sua força nativa, será capaz de abrir o caminho para uma nova Moral da afirmação da vida - uma moral do super-homem - que substituirá a Moral dominante da negaçã̀o da vida, representada pelo moralismo platônico-cristão. Tal o núcleo do discurso desconstrutivista de Nietzsche com relação a toda a tradição moral codificada na Ética, que o faz incluir entre os mestres da suspeita e explica, mais sem dúvida do que o fascinante brilho literário, a enorme influência da sua obra na cultura do nosso século" (Vaz, Escritos de filosofía IV: introdução à ética filosófica, 1999, p. 413).

21. "No procedimento genealógico há a tentativa de construir uma Tipologia da moral. A partir da História natural da moral o genealogista constata a cristalização de dois tipos: a moral dos senhores (Herren-Moral) e a moral dos escravos (Sklaven-Moral)" (Araldi, Para uma caracterizaçäo do niilismo) na obra tardia de Nietzsche, Cademos Nietzsche, São Paulo, v. 5, 1998, p. 78). 
Percebe-se, no correr da história, que as palavras 'bom' e 'mau' estão carregadas de significado. Ora, como entendedor da filologia, o procedimento de Nietzsche é o de analisar que sentidos a história se incumbiu de mascarar por detrás destas palavras, desvelando-lhes o significado. Eis a declaração de Nietzsche acerca de sua pesquisa:

“Alguma educação histórica e filosófica e certo tato inato, delicado para as questões psicológicas, depressa transformaram o meu problema neste outro: o bem e o mal? Eque valor têm em si mesmos? Foram ou não favoráveis ao desenvolvimento da humanidade? São um sintoma funesto de empobrecimento vital, de degeneração?" (Nietzsche, A Genealogia da Moral, 1991, p. XI).

E a constatação de Nietzsche, no que pertine às principais palavras da moral, 'bom' e 'mau' é arrasadora, pois as diversas línguas revelam traços semânticos comuns, ${ }^{22}$ indicando em 'bom' uma noção de 'nobreza' e, em 'mau', de 'servilismo' :23

"A indicação do verdadeiro método foi-me dada por esta pergunta: qual é, segundo a etimologia, o sentido da palavra "bom" nas diversas línguas? Então descobri que esta palavra em todas as línguas deriva de uma mesma transformação de idéias; descobri que, em toda a parte, a idéia de "distinção", de "nobreza", no sentido de ordem social é a idéia-mãe donde nasce e se desenvolve necessariamente a idéia de "nobre" no sentido de

22. Também neste trecho: "Em minha peregrinação através das morais mais refinadas e mais grosseiras que reinaram e ainda reinam, constatei a repetição e a conexão de certos traços característicos, de modo que estou prestes a descobrir dois tipos fundamentais e uma diferença também fundamental. Existe a moral dos senhores e a dos escravos; se concluirá prontamente que nas culturas mais elevadas e cruzadas se encontram tentativas de conciliaçāo entre as duas morais, mas freqüentemente ainda uma confusão das mesmas, fruto de mal-entendidos recíprocos e talvez da coexistência de uma ao lado da outra - isso, tambéın pode ser encontrado em indivíduos, numa só alma" (Nietzsche, Além do bem e do mal, 2001, p. 230).

23. Esta idéia é reforçada em Além do bem e do mal: "A moral dos escravos é, basicamente, uma moral utilitária. Eis aqui o centro de onde se originou a famosa oposição "bem" e "mal", ao mal se atribui instintivamente uma certa potência, uma periculosidade, uın certo terror, uın refinaınento, uma força, não despreziveis. Segundo a moral dos escravos, o mal incute também "terror", segundo a moral dos senhores, é precisamente o "bom" que inspira terror porque quer inspirá-lo, enquanto o homem "mau" é tido como um ser desprezível" (Nietzsche, Além do bem e do mal, 200I, p. 233). "O juízo ruim era estabelecido por esses mesmos homens para designar o homem baixo, vulgar, e seu respectivo fazer” (Azeredo, Nietzsche e a dissolução da moral, 2000, p. 50). 
"privilegiado quanto à alma". E este desenvolvimento é sempre paralelo à transformação das noções "vulgar" "plebeu" "baixo" na noção de "mau" O exemplo mais evidente desta última metamorfose é a palavra alemã schlecht (mau), que é idêntica à palavra schlicht (simples); compare-se schlichtsweg (simplesmente) e schlechterdings (absolutanente), e que sua origem designa o homem simples, o homem plebeu" (Niclissche, A genealogia da moral, 1991, p. X).

É dos arcanos da História que provêm estas noções, seja da etimologia grega da palavra ética (éthos - esthlos), ${ }^{24}$ seja da análise das práticas sociais mais comuns da Antiguidade, seja das relações entre devedor e credor, ${ }^{25}$ seja dos sacrifícios religiosos da mais longínqua data, ${ }^{26}$ seja da verificação de quanto a moral sacerdotal e os cultos antigos continuam presentes no espírito das pessoas. As idéias de 'puros' e 'impuros' decorrentes dos processos de purificação sacerdotal estão aí para indicar isto:

"Deste modo a oposição "puro" e "impuro" serviu
primeiramente para distinguir as castas e ali se
desenvolveu mais tarde uma diferença entre "bom" e
"mau" no sentido já não limitado à casta. Evitemos
atribuir à idéia de "puro" e "imıuro" um sentido
demasiado rigoroso, demasiado lato, e menos ainda um
sentido simbólico. A palavra "puro" designa simplesmente

24. "A palavra esthlos significa "alguém queın é", alguéın que é real, que é verdadeiro; depois, por uma modificação subjetiva, o verdadeiro vem a ser verídico: nesta fase de transforınação da idéia vemos que a palavra que a expressa vem a ser a contra-senha da nobreza, é tomado em absoluto o sentido de "nobre", por oposição a homem "embuskiciro" da plebe, segundo o concebe e descreve Theognis; até que, por fiın, quanto à nobreza da alma, é ao mesıno tempo o que quer que seja maduro e adocicado" (Nietzsche, A genealogia da moral, 1991, p. 6).

25. "Retomemos a nossa investigação onde a deixamos. O sentimento de dever, da obrigação pessoal, tem origem, segundo vimos, nas mais antigas e mais primitivas relações entre os indivíduos, as relações entre o credor e o devedor; aqui pela primeira vez, a pessoa opôs-se à pessoa e inede-se com ela" (Nietzsche, A genealogia da moral, 1991, p. 39).

26. "Os deuses, como afeiçoados aos espetáculos cruéis: como ressalta ainda esta noção primitiva em meio da nossa civilização européia! Leiam-se Calvino e Lutero. Os gregos condimentavann a felicidade dos seus deuses, com os prazeres da crueldade. Como olhavam os deuses de Homero o destino dos homens? Que idéia tinhain da guerra de Tróia e de outros horrores trágicos? Neste ponto não há dúvida: eram brinquedos que alegravam os deuses, e como o poeta é de uma espécie mais "divina" que o resto da humanidade, também para ele eram brinquedos..." (Nietzsche, A genealogia da moral, 199J, p. 38). 
"um homem que se lava" que se abstém de certos alimentos insalubres, que não coabita com as mulheres sujas da plebe e que tem horror ao sangue e nada mais. Por outro lado, a conduta característica de toda a aristocracia sacerdotal indica como esta oposição de valores pode espiritualizar-se e acentuar-se" (Nietzsche, A genealogia da moral, 1991, p. 7).

Da escravidão antiga, do servilismo, da opressão, da aristocracia sacerdotal são oriundos os principais arquétipos da moralidade e os principais conceitos que pré-julgam as coisas dicotomicamente (mau como desprezível, como ínfimo, como repugnante, como sujo, como pobre, como plebeu...). ${ }^{27}$ Este cadenciamento de raciocínios é que levou à universalização de certos valores, e à cristalização de categorias sócio-econômicas como morais e religiosas.

Os escravos e plebeus, identificados com a inferior condição na qual sc encontravam, em oposição, passam a erigir seus contra-valores aos da nobreza e da aristocracia. À ação (ao valor), da aristocracia (valor fundado na superioridade), advém uma re-ação (um contra-valor), dos plebeus (contra-valor fundado no ódio): ${ }^{2 \times}$

"Enquanto toda a moral aristocrata nasce de uma triunfante afirmação de si mesma, a moral dos escravos opõe $11 \mathrm{~m}$ "não" a tudo o que não é seu; este "não" é o seu ato criador. Esta mudança total do ponto de vista é própria do ódio: a moral dos escravos necessitou sempre de estimulantes externos para entrar em ação; a sua ação é uma reação." (Nietzsche, A genealogia da moral, 1991, p. 11).

A luta dos escravos (dos contra-valores) em face dos nobres (dos valores), e, portanto, do 'bem' contra o 'mal', surge a partir dos esforços do povo judeu, como historia Nietzsche:

27. "O medo tunda a moral de escravos, uma vez que ele teme aqueles que são potentes e diferentes dele" (Azeredo, Nietzsche e a dissoluçäo da moral, 2000, p. 64).

28. Assim, bom e mau são conceitos arraigados a noções de bom e ınau oriundas de conflitos de classe: "E tão-pouco é único o conceito "bom". Perguntai aos escravos qual é o "mau", e apontarão a personagem que para a moral aristocraftica é "bom", isto é, o poderoso, o dominador. Simplesmente os escravos olham para ele de viés, com o olhar venenoso de rancor" (Nietzsche, A Genealogia da Moral, 1991, p. 14). 
"Os judeus - "povo nascido da escravidão" como disse Tácito em uníssono corn toda a Antiguidade, "povo eleito entic todos os povos" como eles mesmos dizer e crêemlevaram a cabo essa milagrosa inversão de valores que deu à vida durante milênios um novo e perigoso atrativo. Os profetas judeus fundiram numa só definição o "rico" o "impio" o "violento" o "sensual" e, pela primeira vez, colocaram a pecha da infâmia à palavra "mundo" Nesta inversão de valores (que fez também da palavra "pobre" sinônimo de "santo" e de "amigo") é que se fundamenta a importância do povo judeu, com ele, em moral, começa a insurreição dos escravos" (Nietzsche, Alérn do bem e do mal, 2001, p. 131).

E, deve-se acrescentar que, segundo Nietzsche, esta insurreição que é fruto do ódio levou o próprio Jesus Cristo à crucifixão:

"Compreendeis por que é que esta coisa necessitou de dois mil anos para triunfar?... Não é estranho: de longe é sempre dificil ver. Sobre o tronco da árvore da vingança e do ódio-e é isto o que seu deu-do ódio judaico, do ódio mais profundo e mais subline que o mundo jamais conhecera, do ódio criador do ideal, do ódio transmutador dos valores, do ódio sem semelhante na Terra, do tronco deste ódio saiu uma coisa incomparável, um "amor novo": mais profunda e a mais sublime forma do amor. Mas não se creia que o amor se desenvolver sobre este troco (único em que podia desenvolver-se) como antítese desta vingança e deste ódio. Ao contrário, o amor saiu deste ódio como una coroa triunfante, mas que, no novo domínio da pureza, da luz e do sublime persegue os mesnos fins que o ódio: a vitória, a conquista, a sedução. Este Jesus de Nazaré, este evangelho encarnado do amor, este "Salvador" que trazia aos pobres, aos enfermos e aos pecadores a bem-aventurança e a vitória, não era ele precisamente a sedução na sua forma mais irresistivel, a sedução que, por um rodeio, havia de conduzir os homens 
a adaptar os valores judaicos? O povo de Israel, ao ferir o Salvador, seu aparente adversário, não feriu o verdadeiro objeto do seu ódio sublime?" (Nietzsche, A genealogia da moral, 1991, p. 10).

Desta luta entre escravos e senhores surge um fruto: a moral européia, mediocrizada, massificada, degenerada e medrosa, tacanha c enfadonha, que havcrá de ser o objeto das mais profundas críticas do martelo de Nietzsche:

"O que agora nos inspira medo é a multiplicação assombrosa do homem, do gusano mesquinho e débil, que pretende ser o "homem superior"; em meio da enorme neurastenia, cansaço e senilidade da Europa, ainda se considera o homem como um ser robusto e cheio de vida" (Nietzsche, A Genealogia da Moral, 1991, p. 16).

Disto tudo decorre uma forte onda de tendências ascéticas, purificadoras, moralizantes e empedernidas de controle do comportamento social e manutenção da tradição aristocrática. A moral dos escravos ressai como a moral do medo e da opressão, da fuga e da responsabilidade, e, sacrimentada pela história, transporta-se para os dias atuais para determinar como devem ou não devem agir as pessoas.

Tenha-se presente que nada do que aparenta ser, realmente, em moral, efetivamente o é:

"Seja qual for o ponto de vista no qual nos coloquemos, deve ser reconhecido que a falsidade do mundo em que acreditamos viver é a coisa mais verdadeira e firme que nossa visão pode apreender" (Nietzsche, Além do Bem e do Mal, 2001, p. 58).

Tudo o que possui uma aparência de 'bom' e de 'belo', de fato, se originou das entranhas as mais horrendas da história, sendo insculpidas e contornadas na consciência coletiva aos poucos, ao preço de muita dor, de muito sacrifício, de muito sangue, e de muita injustiça:

"Recorden-se os antigos castigos na Alemanha, entre os outros a lapidação (já a lenda fazia cair a pedra do moinho sobre a cabeça do criminoso), a roda (invenção germânica), o suplício da força, o esmagamento sob os 
pés dos cavalos, o emprego do azeite ou do vinho para cozer o condenado (isto ainda no século XIV e no século $X V$ ), o arrancar os peitos, o expor o malfeitor untado de mel sob un sol ardente às picadas das moscas. Em virtude de semelhantes espetáculos, de semelhantes tragédias, conseguiu-se fixar na memória cinco ou seis "não quero" cinco ou seis promessas, a fin de gozar as vantagens de uma sociedade pacífica e com estas ajudas da memória, "entrou na razão!". Ah! A razão, a gravidade, o domínio das paixões, toda esta maquinação infernal que se chama reflexão, todos os privilégios pomposos do homem, quão caro custaram! Quando sangue e quanta desonra se encontra na fundo de todas estas "coisas boas"!" (Nietzsche, A Genealogia da Moral, 1991, p. 32).

Mais que isto, Nietzsche ainda diz que os principais c unceitos das relações humanas se organizaram e se estabeleceram a partir das relações entre credor e devedor, e das práticas de fazer sofrer pelo primeiro em detrimento do segundo:

"É nesta esfera que têm origens os conceitos morais "falta" "consciência" "dever" "santidade do dever". Estas idéias, como tudo o que é grande sobre a terra, foram regadas com sangue. Enão poderiamos dizer que este mundo nunca perdeu de todo certo cheiro a sangue e a tormentos? (ainda o imperativo categórico do velho Kant se ressente de crueldade...) Este encanamento das idéias "falsas" $e$ "dor" comę̧ou assim a formar-se. Mas, como pode a dor compensar. as dividas? Muito simplesmente: o "fazer" sofrer causa um prazer imenso à parte ofendida: fazer sofrer! Isto era uma verdadeira "festa" Tanto mais grata, repito quanto maior era o constante entre a posição social do credor e a do devedor" (Nietzsche, A genealogia da moral, 1991, p. 35).

Em Nietzsche, portanto, não há esta moral universal e racional que pretendem dizer inata alguns fïlósofos (ao estilo kantiano). Na narrativa de Nietzsche, a razão não é criadora, e sim simples vítima do processo de universalização de certos valores. Há, sim, historicidade e vontade de poder em exercício, assim como fuga da 
condição humana. A moral passa a significar paralisação no tempo e no espaço, autocondicionamento de um povo sobre si mesmo, luta encarnecida de si consigo mesmo, castigo da alma contra o corpo, do espírito contra a vida, da psiché contra o instinto. Eis as contundentes palavras de Nietzsche que denunciam o desapego do homem de si, em nome de um certo procedimento de tortura psíquica:

"Uma obrigação para com Deus: esta idéia foi porém o instrumento de tortura. Imaginou-se Deus como um contraste dos seus próprios instintos animais e irresistiveis e deste modo transformou estes instintos em faltas para com Deus, hostilidade, rebelião contra o "Senhor" "Pai" $e$ "Princípios do mundo" e colocando-se galantemente entre "Deus" eo "Diabo" negou a Natureza para afirmar o real, o vivo, o verdadeiro Deus, Deus santo, Deus justo, Deus castigador; Deus sobrenatural, suplício infinito, inferno, grandeza incomensurável do castigo e da falta. Há uma espécie de demência da vontade nesta crueldade psíquica" (Nietzsche, A genealogia da moral, 1991, p. 59).

Perceba-se que a moral tradicional, em verdade, é fruto do conflito, do ódio de uns contra os outros, é embate, é confronto, é dor, é suplício, é auto-condenação, é castigo.". Isto tudo burilado e introjetado ao longo dos séculos deu origem à hipocrisia moral européia do século XIX, afirma Nietzsche, des-construindo a realidade dos valores negativos na tentativa de re-construi-los positivamente.

E, mais ainda, deve-se, pela vontade de poder, superar a crise de valores e re-construir-se o passado sobre os andrajos e restos de si mesmo, para o prelúdido de um futuro moral radicalmente oposto a este ao qual se está acostumado:

"Veio para que vós, meus amigos, vos desgostásseis das velhas fórmulas que tereis aprendido dos mentirosos e dos insensatos;

para que vos canseis das palavras "recompensa" "represálias" "castigo", "justa vingança";

29. "Ver sofrer, alegra; fazer sofrer, alegra mais ainda: há nisto uma antiga verdade "huınana, demasiado humana". à qual talvez subscrevessem os macacos, porque, de fato, diz-se com a invenção de certas crueldades anunciavaın já o homem e precediam a sua vinda. Sem crueldade não há gozo, eis o que nos ensina a ınais antiga e remota história do homeın; o castigo é uma festa" (Nietzsche, A genealogia da moral, 1991, p. 36). 
para que vos canseis de dizer que 'uma ação é boa quando desinteressada." (Nietzsche, F W., Assim falava Zaratrusta, 1973, p. 105).

3.2. A transvaloração: superação da moral tradicional.

É possível superar a moral tradicional, afirma Nietzsche, deixando-se o homem viver como homem, e podendo-se exercitar a criatividade como artífice de outras éticas, que não aquelas que se identificam com as dicotomias, com as divisões, com o negativo, com o sanguinário, com o guerreiro, com o passado, com a revanche social... Aliás, o papel de toda filosofia do futuro é exatamente este! Nada mais se deseja senão que o homem seja inteiramente homem, e que alcance a plenipotência de sua condição humana. Deve-se romper com este raciocínio que permitiu a domesticação do homem por si mesmo:

"Nada obstante o individuo ser o marco terminal do processo de adestramento do homem, interpôs-se entre a fase inicial e a final dessa formação o homem domesticado" (Azeredo, Nietzsche e a dissolução da moral, 2000, p. 102).

A crítica genealógica da moral, que identificou a moral dos senhores em oposição à moral dos escravos como causa fundante dos principais conceitos éticos do Ocidente, é o instrumento necessário para superar o passado e construir o futuro, para des-construir o passado e re-fundar o futuro em novas bases. ${ }^{31}$ Isto importa em romper as barreiras solidificadas com o tempo e erigir novos moldes, para que o futuro se abra em novas dimensões, que não aquelas que vêm se desenrolando há séculos. Eis o prelúdio de uma filosofia do futuro!?' É necessário reprimir a moral, para que emerjam outras morais:

"Ora, o fim do processo de formação do homem requer a sua plena realização, que é atingida somente mediante a repressão da própria moral" (Azeredo, Nietzsche e a dissolução da moral, 2000, p. 100).

30. Eis o papel esperado do filósofo por Nietzsche: "O filósofo do futuro deve ser um criador de valores, mas é preciso, primciro, destruir as antigas tábuas de valor" (Azeredo, Nietzsche e a dissolus đano) da moral, 2000, p. 179).

31. A antevisão de Nietzsche é real sobre o surgimento dos filósosos da dúvida: "Esse terá que aguardar a chegada de uma nova espécie de filósofos, diferentes em gostos e inclinações a seus predecessores: filósofos do perigoso "talvez", em todos os sentidos da palavra. Falo com toda a sinceridade, pois vejo a vinda desses novos lilósolos..." (Nietzsche, Além do bem e do mal, 2001, p. 21). 
Haverá de surgir no futuro uma nova condição humana, como reflexo deste processo de re-abertura do passado (re-lido e re-interpretado nietzschianamente), de libertação, de liberdade, de consciência plena, de plenipotência ética. Eis o fruto desta escavação genealógica, entrevê Nietzsche:

"O indivíduo soberano prescinde da justiça, assim como da lei, pois ele é 'fruto maduro que, mediante a moralidade do costume e a própria justiça, ambos situados na pré-história da humanidade, tornou-se primeiramente responsável para depois tornar-se leve, livre, irresponsável" (Azeredo, Nietzsche e a dissolução da moral, 2000, p. 115).

Ora, então, a história haverá de mostrar que o homem do futuro é aquele que não mais é responsável, não mais carece da justiça (que nunca existiu), não deve nada a ninguém, mas que é tamanhamente autônomo que se torna capaz de superar a infância da humanidade, escrava que era do dever, da moral tradicional e da responsabilidade moral, da crença metafísica e da autoflagelação. Eis a pós-história da humanidade. ${ }^{32}$

Para desvendá-la não seriam suficientes os olhos míopes e canhestros dos filósofos tradicionais, de inspiração metafísica e moralista, que sempre se detiveram a generalizar suas experiências pessoais como sendo experiências universais e universalizáveis:

"Os filósofos sem exceção olham-se sempre com uma seriedade ridícula, algo de muito clevado, de muito solene, não apenas deviam ocupar-se da moral, como ciência, mas desejavam estabelecer os fundamentos da moral, $e$ todos acreditaram firmemente tê-lo conseguido, mas a moral era encarada por eles como coisa "dada" Quão distante de seu orgulho canhestro se encontrava a tarefa, aparentemente irrelevante e inconcludente, de uma simples descrição, já que una tal incumbência requer mãos $e$ sentidos inefavelmente delicados. Esta é a razão, sem dúvida, de os moralistas conhecerem tão grosseiramente

32. "A supressão da justiça é uma decorrência da própria supressão da ação da espécie sobre o indivíduo e, com isso, da passagem da pré-história à pós-história" (Azeredo, Nietzsche e a dissolução) da moral, 2000, p. 115). 
os facta da moralidade, por intermédio de compendios arbitrários ou ainda por meio de uma abreviação casual, por exemplo, aquela moral de seu ambiente, de sua própria classe, da sua igreja, do espírito do tempo em que vivem. do seu clima, de seu pais e justamente por isso estavam mal informados acerca das nações, das épocas, da história dos tempos passados; jamais estiveram face a face com os verdadeiros problemas da moral que se apresentam apenas quando se verifica o confronto de muitas morais. Na assim chamada "ciência da moral" faltava precisamente, por mais que isso pareça estranho, o próprio problema da moral e não havia mesmo a suspeita da existéncia de algum problema" (Nictzsche, Além do Bèm e do Mal, 2001, pp. 119-120).

Eis o anúncio do surgimento do super-homem nietzschiano, nestc contexto, como forma de libertação do homem pelo homem, pela boca de Zaratrusta:

"E Zaratrusta dirigitu-se ao povo nestes termos:

Eu vos anuncio o Super-homem. Ohomem só existe para ser superado. Que fizestes para o superar?"

"Que é o macaco para o homem? Uma irrisão on uma dolorosa vergonha. Tal será o homem para o Superhomem: uma irrisão ou uma dolorosa vergonha" (Nietzsche, F. W., Assim falava Zaratrusta, 1973, p. 12).

4. Justiça, sociedade e Direito.

A sociedade, da forma como se esquematiza, e do modo como se organiza, dentro da Jógica das explicações anteriores, nada mais é do que uma estrutura mantida dentro da dicotomia credor-devedor. Leia-se:

"Nos antigos tempos, e quase também nos modernos, as" relaş̃es da communidade com os sens membros são as de um credor com os seus devedores. Viver em sociedade quer dizer estar protegido na vida e fazenda, gozar a paz e da confiança de estar livre de certos danos e perigos aos quais continua exposto o que vive fora - um alemão sabe o que 
Elend significava primitivamente - desde de que se viva em paz com a comunidade. Em caso contrário, o que sucederá? A comunidade, o credor far-se-ão pagar a sua divida. Aqui se trata só de um prejuízo: o culpado é também violador do compromisso e falta à sua palavra para com a comunidade que lhe assegurava tantas regalias e prazeres. $O$ culpado é um devedor que não só paga as dividas, senão que também ataca o credor: desde esse momento não só se priva de todos estes bens e regalias, senão que se recorda de todas a importância que tinha a sua pessoa. A cólera dos credores ofendidos constitui-o outra vez no estado selvagem, põe-no fora da lei, recusathe proteção e contra ele pode já cometer-se qualquer ato de hostilidade. $O$ "castigo" é simplesmente a imagem, a "mímica" da conduta normal a respeito do inimigo detestado, desarmado e abatido, que perdeu todos o direito não só à proteção mas também à piedade; é o grito de guerra, o triunfo do vae victis em toda a sua inexorável crueldade. Isto explica como a própria guerra e os sacrificios guerreiros revestiram todas as formas sob as quais aparece o castigo na história" (Nietzsche, A genealogia da moral, 1991, p. 40).

Ora, em Nietzsche é a sociedade a origem das tradições e das formas de organização e controle da conduta. A reflexão nietzschiana, num rápido apanhado da questão, em verdade, alcança com a força do martelo a origem dos pré-conceitos morais, uma vez que as castas, as organizações hierárquicas, os cultos coletivos, as crenças compartilhadas é que dão força e sustentação para a moral tradicional, que acaba se alimentando das fraquezas desta própria sociedade que the serve de cômodo e aconchegante berço. As noções de dever, de responsabilidade, de ônus moral, de peso ético, de dívida social, de má consciência, entre outras, têm uma só origem, a sociedade:

"Chegando a este ponto, vou dar à minha hipótese acerca da origen da "má consciência" uma expressão provisória, a qual, para ser compreendida, necessita ser meditada e ruminada. A má consciência é para mim o estado mórbido em que devia ter caido o homem quando sofreu a 
transformação mais radical que nunca houve, a que nele se produz quando se viu acorrentado à argola da sociedade e da paz" (Nietzsche, A genealogia da moral, 1991, p. 50).

Com isto quer-se dizer que a moral do grupo impera sobre a moral particular, disto advindo as tradicionais pressões do maior número sobre o menor número, apagando-se as chamas das fogeiras individuais, para que sobreviva somente a fogueira central dos valores morais preponderantes herdados desde longa data e repetidos inconscientemente ao longo dos séculos. Mais uma vez, a vontade potência que desabrocha na individualidade é reprimida pela opressão da moral coletiva.

Não se pense muito menos que o Estado tem suas origens contratuais, correspondendo às necessidades de ordem e paz da sociedade. Ele surge, na prospecção genealógica, como todo fato social e moral surge, ou seja, das entranhas da prática do passado histórico, que não tem a relatar idéias romanceadas e racionais, mas sim fatos sórdidos e violentos, injustiças e práticas de opressão, dor, desespero e dominação. Não se haveria de estranhar que a origem do próprio Estado adviesse de um embate, e não de um contrato racional, com amplo e pleno acordo dos pactuantes, com vistas à implantação da justiça e da harmonia sociais.

Bem entendida, a lição é a de que o Estado passou a reinar como idéia central de organização da sociedade quando a primeira horda de aristocratas, pela força, derrotou, ao preço de lágrimas, suor c sanguc, qualquer grupo primitivo, e impôs a sua paz, assim como seus valores, suas crenças e suas ideologias. Segundo Nietzsche, eis a origem do Estado, crua e nua, simples e sem retoques:

"Em segundo lugar que a submissão a uma norma fixa, de una população que até então careceria de norma e de freio, tendo começado por un ato de violência, não podia ser levada a cabo senão por atos de violência; e que, por conseguinte o "Estado" primitivo teve de entrar em cena com todo caráter de una espantosa tirania, de uma máquina sangrenta e desapiedada, e assim continuou, até que, por fim, uma tal matéria brutal de animalidade foi abrandada e tornada manejável, ainda que não "modelada" Emprego a palavra "Estado" mas é fácil compreender que me refiro a uma horda qualquer de aves de rapina, uma raça de conquistadores e de senhores, que com a sua organização guerreira deixaram cair sem 
escrúpulos as sua formidáveis garras sobre uma população talvez infinitamente superior em número, mas ainda inorgânica e errante. Tal é a origem do "Estado"; creio que já foi bastante refugada aquela opinião que fazia remontar a sua origem a um" "contrato". Ao que nascen para mandar, ao que se sente poderoso no seu andaime e na sua obra, que lhe importam os contratos? Não se pode contar com tais elementos: chega, com o destino, sem causa, sem razão, sem objetivo, sem pretexto, com a rapidez do raio, por demasiado terríveis, rápidos, $e$ contundentes para que possam ser objeto de ódio" (Nietzsche, A genealogia da moral, 1991, p. 53).

Este mesmo Estado que se forma, passa a criar e a ditar suas próprias regras, surgindo daí a legislação e as normas jurídicas. Nesta perspectiva, o que é o direito senão este expediente de dominantes para subjugar dominados, ${ }^{33}$ algo do que, em tempos pós-históricos, se haverá de dispensar por completo, pois o super-homem não precisa de regras externas, e sim apenas internas, uma vez que haverá de ter superado a condição raquítica e dependente na qual se encontra enquanto atrelado ao jugo do presente determinado pela moral tradicional.

Conclusões.

A obra de Nietzsche representa uma forte ruptura com a moral tradicional, abalando, em pleno século XIX, crenças fortemente arraigadas ao homem de sua época. É exatamente esta a nota peculiar de sua atitude frente ao mundo. Apesar das fortes reações dos círculos mais tradicionais às suas posturas filosóficas, a filosofia moral niclzschiana repercule a ponto de delerminar lorte inlluxo de idéias para o século XX. É assim que se pode dizer que fornece horizontes interessantes de discussão, na medida cm que dela se destacam os seguintes aspectos:

a. necessidade de proceder à genealogia e à avaliação dos valores construídos historicamente pela moral;

33. Assim, deve-se ler: "Para o filósofo alemão, em todos os tempos, o direito sempre esteve ligado aos fortes e poderosos como impositores da lei e, a partir disso, do que é justo e injusto. Não existe justo em si, mas tão somente em relação a uma lei estabelecida" (Azeredo, Nietzsche e a dissolução da moral, 2000, p. (16). 
b. necessidade de transvaloração dos valores, em direção à mudança c à superação dos modelos arraigados pelo passado na estruturação dos deveres éticos;

c. projeção da máxima liberdade como correspondente necessário e eficaz (la superação da metafísica e da opressão da tradição moral da humanidade;

d. ruptura com as estruturas da moral dos escravos em face da moral dos senhores, em direção à pluralidade ética, à auto-responsabilidade, à idade adulta do ser humano, consciente de si e livre para dar vazão à sua vontade de potência.

Junto com estas reflexões fica a antevisão feita pelo filósofo, no final do século XIX, acerca das marcas que haveriam de irromper na Europa futura:

“Um pensador que fosse responsável pelo futuro da Europa, em todos os seus projetos, deveria incluir os judeus e os russos, fatores seguros e prováveis na liça, no grande confronto de forças" (Nietzsche, Além do Bem e do Mal, 2001, p. 213).

São Paulo, junho de 2003. 
Bibliografia.

ABBAGNANO, Nicola. Dicionário de filosofia. Trad. Alfredo Bosi. São Paulo: Martins Fontes, 2000.

ARALDI, Clademir Luís. Para uma caracterização do niilismo na obra tardia de Nietzsche, Cadernos Nietzsche, v. 5, pp. 75-94, São Paulo, Grupo de Estudos Nietzsche; Discurso, 1998.

AZEREDO, Vânia Dutra de. Nietzsche e a dissolução da moral. Sãc Paulo: Discurso Editorial; Editora UNIJUÍ, 2000.

BELO, Fernando. Leituras de Aristóteles e de Nietzsche: a poética sobre a verdade e a mentira. Lisboa: Fundação Calouste Gulbenkian, 1994.

HEINEMANN, F. A filosofia no século XX. 4. ed. Trad. Alexandre F. Morujão. Lisboa: Fundação Calouste Gulbenkian, 1993.

JASPERS, Karl. Nietzsche et le christianisme. Trad. Jeanne Hersch. Paris: Minuit, 1949.

MASIP, Vicente. História da filosofia ocidental. São Paulo: EPU, 2001.

NIETZSCHE, F. Ecce homo: como cheguei a ser o que sou. Trad. Lourival de Q. Henzel. 4. ed. São Paulo: Brasil, s.d.

NIETZSCHE, F. W. A genealogia da moral. 3. ed. São Paulo: Moraes, 1991.

NIETZSCHE, F. W. Além do bem e do mal. Trad. São Paulo: 2001.

NIETZSCHE, F. W. Assim falava Zaratrusta. Trad. Alfredo Margarido. Lisboa: Guimarães, 1973.

NIETZSCHE, F. W. Aurore: réflexion sur les préjugés moraux. Trad. Henri Albert. Paris: Mercure de France, 1912.

NIETZSCHE, F. W. Opere 1870/1881. Milano: Newton, 1993.

NIETZSCHE, F. W. Opere 1882/1895. Milano: Newton, 1993.

SAFRANSKI, Rüdiger. Nietzsche: biografia de uma tragédia. Trad. Lya Luft. São Paulo: Geração, 2001.

VAZ, Henrique C. de Lima. Escritos de filosofia IV: introdução à ética filosófica. São Paulo: Loyola, 1999. 